\title{
RESPONSE OF SOME SUGAR BEET VARIETIES TO COMBINATIONS OF NITROGEN AND BORON FERTILIZATION.
}

\author{
Aly, E.F.A. \\ Sugar Crops Res. Inst., Agric. Res. Center, Giza, Egypt
}

ABSTRACT

Two field experiments were conducted at Sakha Agricultural Research Station (Kafr El-Sheikh Governorate) during 2008/2009 and 2009/2010 seasons to investigate the effect of combinations of $\mathrm{N}$ and $\mathrm{B}$ applications on yield and its components as well as quality characteristics of three sugar beet varieties namely: Lola, Pleno and Farida. Nitrogen was added as broadcast, and boron as foliar application at levels $(100 \mathrm{~kg} \mathrm{~N} / \mathrm{fed}+$ zero B), (100 kg $\mathrm{N} / \mathrm{fed}+100 \mathrm{ppm} \mathrm{B})$, and (100 kg N/fed + $150 \mathrm{ppm} \mathrm{B})$.

The obtain results showed that:

1- Root fresh weight $(\mathrm{kg})$, as well as root length and diameter $(\mathrm{cm})$ were significantly improved in both seasons by adding $100 \mathrm{~kg} \mathrm{~N} / \mathrm{fed}+100$ or 150 ppm B. Treatment with $100 \mathrm{~kg} \mathrm{~N} / \mathrm{fed}+150 \mathrm{ppm}$ B significantly increased sucrose $\%$ by ( 4.5 and $3.9 \%)$, extraction sugar\% by (6.2 and $6.0 \%)$, root yield by (11.8 and $10.4 \%)$ and sugar yield by (18.7 and 16.7\%) compared with $(100 \mathrm{~kg} \mathrm{~N} / \mathrm{fed}+$ zero B) treatment in both seasons, respectively. Impurities parameters (K, Na and $\alpha$-amino $\mathrm{N} \%)$, and Alkalinity coefficient were significantly reduced by adding $100 \mathrm{~kg} \mathrm{~N}+150 \mathrm{ppm} \mathrm{B}$ in both seasons.

2- Varieties were significantly different for all traits under this study. Farida variety was superior for root fresh weight by ( 8.5 and $7.2 \%)$, root diameter (7.0 and 5.5\%) and root yield by (5.6 and 4.6\%) compared to Lola variety in the $1^{\text {st }}$ and $2^{\text {nd }}$ seasons respectively, while Lola variety surpassed other varieties in quality traits (sucrose $\%$, extraction sugar\%, and extractability \% and recoverable sugar yield/fed) in both seasons.

3- Applications of nitrogen combined with boron had significant effect on sucrose \%, as well as root and sugar yields ( $\mathrm{t} / \mathrm{fed}$ ) for the studied varieties in both seasons.

4- We can recommend by use $100 \mathrm{~kg} \mathrm{~N} /$ fed combined with Boron at 100ppm to reduce juice impurities and increase the productivity of sugar beet varieties.

Key words: Response, Sugar beet varieties, Nitrogen and Boron fertilization.

\section{INTRODUCTION}

Nitrogen and boron are considered the most important elements affecting sugar beet production in the Egyptian newly reclaimed or even old soils which suffering from insufficient or unavailable contents of these nutrients. The economic yield of sugar beet, that closely related to the sugar accumulation process found to be affected by $\mathrm{N}$-fertilization level. In this respect, Mostafa and Darwish (2001) reported that increasing $\mathrm{N}$ up to $100 \mathrm{~kg} / \mathrm{fed}$ significantly increased length and diameter of root, as well as root and sugar yields/fed. However, root quality as sucrose $\%$ and juice purity was significantly decreased by increasing nitrogen rates. Ismail $\boldsymbol{e t}$. al. (2007) found that root length, root diameter, root fresh weight/plant, root yield, impurities content in roots and sugar loss to molasses were increased by increasing rates of $\mathrm{N}$ from 110 up to $120 \mathrm{~kg} / \mathrm{fed}$, while sucrose $\%$, purity $\%$, extractable sugar\% and extractability $\%$ were decreased. Osman and Shehata (2010) found that increasing nitrogen level up to $120 \mathrm{~kg} / \mathrm{fed}$ significantly increased growth of sugar beet root measurements (length, diameter and fresh weight) and its content of $\mathrm{N}, \mathrm{Na}$ and 
Aly, E.F.A.

alpha amino acids as well as root yield. They showed that adding $90 \mathrm{~kg}$

$\mathrm{N} /$ fed significantly increased sucrose $\%$, purity and sugar yield $t / f e d$.

Boron is essential for providing sugars, which are needed for root growth in all plants. In this connection, Cooke and Scott (1993) mentioned that boron is the most important trace elements needed for sugar beet because, its shortage or without an adequate supply, the yield and quality are very depressed. Gobarah and Mekki (2005) fertilized sugar beet with four levels of boron (zero, 1, 1.5 and $2 \mathrm{~kg} /$ acre). They found that increasing boron rate up to $1.5 \mathrm{~kg} / \mathrm{acre}$ increased root length, diameter and root yield. The root yield increments were estimated by 4.00 and 5.76 t/acre compared with the unfertilized plots. However, increasing boron fertilizer up to $2.0 \mathrm{~kg} / \mathrm{acre}$ resulted in the highest sucrose, recoverable sucrose and juice purity percentages as well as recoverable sugar yield. Kristek and Kristek (2006) studied the effect of foliar application with boron (B) at the rate of $1.0 \mathrm{~kg} \mathrm{~B} / \mathrm{ha}$ compared with the control (without $\mathrm{B}$ application) on sugar beet root yield and quality. They found that root yield was higher by $13.6 \mathrm{t} / \mathrm{ha}$ (19.4\%), sugar concentration higher by $1.46 \%$ and sugar yield higher by 3.15 t/ha (39.5\%). They recommended foliar application with $1.0 \mathrm{~kg} \mathrm{~B} / \mathrm{ha}$ for sugar beet grown in soils characterized by insufficient boron supply. Allen et. al. (2007) stated that sugar beet crop has high requirements for B. Adequate B nutrition is critical for high crop yields and quality. They suggested that boron increases the rate of transport of sugars (which are produced by photosynthesis in mature plant leaves) to actively growing regions and also in developing roots. Abo El-Hamd and Esmail (2008) studied the effect of foliar with B on yield and quality of sugar beet plants. They found that increasing B levels from 100 to $200 \mathrm{ppm}$ as boric acid/fed significantly improved root length, root diameter, root fresh weight/plant and sugar yield/fed. Enan (2011) indicated that the highest values of root diameter, root fresh weight and sucrose\%, as well as root, top and sugar yields/fed at harvesting time were proportional with increasing boron application to $200 \mathrm{ppm}$.

Ouda (2007) studied the influence of nitrogen and boron nutrition balance on growth and yield of sugar beet. The author cleared that increasing $\mathrm{N}$ levels from 60 to $80 \mathrm{~kg} \mathrm{~N} /$ fed significantly increased root yield. Application of $50 \mathrm{ppm}$ B significantly improved root yield. The application of N-B combination at 100 $\mathrm{kg} \mathrm{N}+50 \mathrm{ppm} \mathrm{B/fed} \mathrm{gave} \mathrm{the} \mathrm{maximum} \mathrm{sugar} \mathrm{and} \mathrm{root} \mathrm{yields.}$

Sugar beet seeds sown in Egypt are imported and hence beet varieties should be evaluated under the Egyptian conditions to select the best ones in respect to yield and quality traits. Aly (2006) found that Marathon variety had almost the best values of root length, and diameter and root fresh weight, as well as root and sugar yields/fed. On the other hand, Kawemira variety was the highest one for sucrose, extractable sugar and extractability percentages. Abd El-Aal et. al. (2010) revealed that significant variation in yield productivity and root quality among sugar beet varieties. Kawemira and Gloria varieties followed by Nejma gave the highest sugar yield; whereas, Lola variety exhibited the lowest sugar yield. Oscar poly, Carola, Raspoly, Kawemira and Mont Bianko varieties were more response to added nitrogen fertilizer.

\section{MATERIALS AND METHODS}

Two field experiments were conducted at Sakha Agricultural Research Station, Kafr El-Sheikh Governorate during 2008/2009 and 2009/2010 seasons to study the effect of combinations among nitrogen fertilizer and boron levels $(\mathrm{N}+\mathrm{B})$ on some sugar beet varieties. The applied $(\mathrm{N}+\mathrm{B})$ treatments were $1 \cdots \mathrm{kg}$ $\mathrm{N} /$ fed + zero ppm B, $100 \mathrm{~kg} \mathrm{~N} /$ fed + $100 \mathrm{ppm} \mathrm{B}$, and $100 \mathrm{~kg} \mathrm{~N} / \mathrm{fed}+150 \mathrm{ppm} \mathrm{B}$. The three evaluated sugar beet varieties were Farida and Pleno, imported from

Fayoum J. Agric. Res. \& Dev., Vol.25, No.1, January, 2011 
Holland and Lola from Germany. A split plot design with three replicates was used, where $(\mathrm{N}+\mathrm{B})$ treatments were allocated in the main plots, and the sugar beet varieties randomly distributed in the sub plots. Plot area was $12 \mathrm{~m}^{2}$ $(1 / 350 \mathrm{fed})$ including four rows of $60 \mathrm{~cm}$ width and $5 \mathrm{~m}$ long. Sugar beet was planted on the $2^{\text {nd }}$ week of October in both seasons and harvested after 210 days from sowing.

Nitrogen fertilizer was applied in the form of urea $(46.5 \% \mathrm{~N})$ in two equal doses after thinning and 30 days later. Phosphorus was added before sowing at the rate of $30 \mathrm{~kg} \mathrm{P}_{2} \mathrm{O}_{5} / \mathrm{fed}$ in the form of superphosphate $\left(15.5 \% \mathrm{P}_{2} \mathrm{O}_{5}\right)$. Potassium was applied at the rate of $24 \mathrm{~kg} \mathrm{~K}_{2} \mathrm{O}$ /fed as potassium sulfate $(48 \%$ $\left.\mathrm{K}_{2} \mathrm{O}\right)$. Boron was sprayed as Boric acid $(17 \% \mathrm{~B})$ in two equal doses at age of 65 and 80 days after sowing. Other agricultural practices were applied as recommended for growing sugar beet in the region. Soil samples were taken before sowing for determination the physical and chemical properties for the experimental soil, illustrated in Table (1) that carried out according to A.O.A.C (1995).

Table (1): physical and chemical properties of tested soil.

\begin{tabular}{|c|c|c|}
\hline Soil analysis & $2008 / 2009$ & 2009/2010 \\
\hline \multicolumn{3}{|c|}{ Particle size distribution } \\
\hline Sand\% & 14.2 & 11.4 \\
\hline Silt\% & 29.0 & 30.3 \\
\hline Clay\% & 56.8 & 58.3 \\
\hline Textural class & Clay & Clay \\
\hline \multicolumn{3}{|c|}{ Soluble ions $\left(\mathrm{mq} \mathrm{L}^{-1}\right)$} \\
\hline $\mathbf{C a}^{++}$ & 17 & 23 \\
\hline $\mathbf{M g}^{++}$ & 8 & 4 \\
\hline $\mathrm{Na}^{+}$ & 14 & 24 \\
\hline $\mathbf{K}^{+}$ & 17 & 13 \\
\hline $\mathrm{Cl}^{-}$ & 20 & 16 \\
\hline $\mathrm{SO}_{4}^{-}$ & 8 & 18 \\
\hline $\mathrm{Hco}_{3}^{-}$ & 28 & 30 \\
\hline $\mathrm{Co}_{3}^{-}$ & - & - \\
\hline EC d Sm-1 (soil paste) & 5.6 & 6.2 \\
\hline PH (soil paste) & 8.2 & 8.0 \\
\hline \multicolumn{3}{|c|}{ Available nutrients (ppm) } \\
\hline $\mathbf{N}$ & 135 & 131 \\
\hline $\mathbf{P}$ & 20.8 & 23.1 \\
\hline $\mathbf{K}$ & 288 & 256 \\
\hline B & 0.46 & 0.41 \\
\hline
\end{tabular}

\section{Recorded data:}

At harvest, a random sample of ten roots was taken from each sub-plot to determine:

\section{A. Root growth traits:}

1. Root fresh weight $(\mathrm{kg}) 2$. Root length $(\mathrm{cm}) 3$. Root diameter $(\mathrm{cm})$

\section{B. Juice quality traits:}

Quality traits were determined using an Automatic French System (HYCEL).

1. Sucrose percentage was Polarimetrically determined according to the methods of Le-Docte (1927).

2. Sugar beet impurities including $(\mathrm{K}, \mathrm{Na}$ and $\alpha$-amino $\mathrm{N}$ ) were determined. Potassium (K\%) and Sodium $(\mathrm{Na} \%)$ were determined using Flame Photometer as described by Page (1982), while $\alpha$-amino $\mathrm{N}$ was determined using Hydrogenation method according to Carruthers et al. (1962).

Fayoum J. Agric. Res. \& Dev., Vol.25, No.1, January, 2011 
Aly, E.F.A.

3. Alkalinity Coefficient (AC) was determined from the major non sugars $\mathrm{K}$, $\mathrm{Na}$ and $\alpha$-amino $\mathrm{N}$ as follows: $(\mathrm{AC})=(\mathrm{K} \%+\mathrm{Na} \%) / \alpha$-amino $\mathrm{N} \%$, Devillers (1988)

4. Sugars lose to molasses percentage (SLM\%) was calculated according to Devillers (1988), formula: SLM\% $=0.14(\mathrm{Na}+\mathrm{K})+0.25(\alpha$-amino $\mathrm{N})+0.5$

5. Extractable sugar percentage (Ex.S\%) was calculated as proposed by Dexter et. al. (1967), formula: (Ex.S\%) = Sucrose\% - SLM\% - 0.6

6. Extractability $\%=($ Extractable sugar\%/ sucrose $\%) \times 100$

C. Yields:

Sugar beet plants of inside two rows were up-rooted, topped and weighed to determine root yield $(\mathrm{t} / \mathrm{fed})$ to determine:

1. Root yield ( $\mathrm{t} / \mathrm{fed})$

2. Recoverable sugar yield (ton/fed) was calculated according to Devillers (1988), formula: Recoverable sugar yield $(\mathrm{t} / \mathrm{fed})=$ (root yield (ton/fed) $\mathrm{x}$ Ex.S\%)/100.

Statistical analysis:

Analysis of variance was calculated according to the method described by Snedecor and Cochran (1981). Least significant difference test (LSD) at 5\% level of

\section{RESULTS AND DISCUSSION}

\section{A. Root growth traits}

Data in Table (2) show that applications of $\mathrm{N}$ and B fertilizaters, as well as varieties exhibited high significant effects on root fresh weight $(\mathrm{kg})$, root length $(\mathrm{cm})$ and root diameter $(\mathrm{cm})$ in both seasons.

Increasing nitrogen levels up to $100 \mathrm{~kg} \mathrm{~N} /$ fed with boron up to $150 \mathrm{ppm}$ led to significant increases by $15.7,11.6$ and $6.3 \%$ in $1^{\text {st }}$ season, as well by 13.2 , 10.8 and $7.1 \%$ in the $2^{\text {nd }}$ season in root fresh weight $(\mathrm{kg})$, root length and root diameter $(\mathrm{cm})$ traits, respectively, compared with $(100 \mathrm{~kg} /$ fed $+0 \mathrm{ppm} \mathrm{B})$. These results are in agreement with those obtained by Mostafa and Darwish, (2001), Gobarah and Makki (2005) and Abo El-Hamd and Esmail (2008), who stated that increasing level of $\mathrm{N}$ up to $120 \mathrm{~kg} / \mathrm{fed}$ and or B levels from 100 to $200 \mathrm{ppm}$ significantly improved root characters.

Significant differences among varieties were cleared in Table (2). Farida variety was superior to other varieties by $8.5 \%$ and $7.2 \%$ for root fresh weight and by $7 \%$ and $5.4 \%$ for root diameter traits in both seasons, respectively. While, Lola variety was the highest one for root length and surpased the other two varieties by $5.2 \%$ and $4.2 \%$ in the two seasons, respectively. Similar results were previously obtained by, Aly, (2006).

The interaction between fertilizer applications $(\mathrm{N}+\mathrm{B})$ was of significant effect for root diameter in the $2^{\text {nd }}$ season only, in favour to Farida fertilized by $100 \mathrm{~kg} \mathrm{~N}$ and $150 \mathrm{ppm} \mathrm{B/fed.}$ 
RESPONSE OF SOME SUGAR BEET VARIETIES TO.

Table (2): Root fresh weight $(\mathrm{kg})$, root length $(\mathrm{cm})$ and root diameter (cm) as affected by nitrogen combined with boron fertilizer applications of three sugar beet varieties in 2008/2009 and 2009/ 2010 seasons.

\begin{tabular}{|c|c|c|c|c|c|c|c|c|}
\hline \multirow{3}{*}{ Kg N/fed + Bpppm } & \multicolumn{8}{|c|}{ Root fresh weight $(\mathrm{kg})$} \\
\hline & \multicolumn{4}{|c|}{$2008 / 2009$ season } & \multicolumn{4}{|c|}{ 2009/2010 season } \\
\hline & Lola & Pleno & Farida & Means & Lola & Pleno & Farida & Means \\
\hline $100 \mathrm{~N}+$ zero $\mathrm{B}$ & 0.820 & 0.865 & 0.872 & 0.852 & 0.862 & 0.875 & 0.904 & 0.880 \\
\hline $100 \mathrm{~N}+100 \mathrm{ppm} \mathrm{B}$ & 0.919 & 0.954 & 0.997 & 0.956 & 0.937 & 0.977 & 1.016 & 0.977 \\
\hline $100 \mathrm{~N}+150 \mathrm{ppm} \mathrm{B}$ & 0.931 & 0.995 & 1.031 & 0.986 & 0.960 & 0.992 & 1.037 & 0.996 \\
\hline Means & 0.890 & 0.938 & 0.966 & & 0.920 & 0.948 & 0.986 & \\
\hline \multicolumn{9}{|l|}{ LSD at $5 \%$} \\
\hline Fertilization $(\mathrm{F})$ & & & & 0.086 & & & & 0.027 \\
\hline Varieties (V) & & & & 0.034 & & & & 0.031 \\
\hline$(\mathrm{FxV})$ & & & & NS & & & & NS \\
\hline \multicolumn{9}{|c|}{ Root length $(\mathrm{cm})$} \\
\hline $100 \mathrm{~N}+$ zero $\mathrm{B}$ & 27.8 & 27.9 & 27.5 & 27.7 & 27.5 & 26.7 & 26.3 & 26.8 \\
\hline $100 \mathrm{~N}+100$ ppm B & 32.0 & 30.5 & 29.9 & 30.8 & 30.5 & 30.5 & 29.6 & 30.2 \\
\hline $100 \mathrm{~N}+150 \mathrm{ppm} \mathrm{B}$ & 32.0 & 30.7 & 30.0 & 30.9 & 30.3 & 29.6 & 29.0 & 29.7 \\
\hline Means & 30.6 & 29.7 & 29.1 & & 29.5 & 28.9 & 28.3 & \\
\hline \multicolumn{9}{|l|}{ LSD at $5 \%$} \\
\hline Fertilization (F) & & & & 1.4 & & & & 1.3 \\
\hline Varieties (V) & & & & 0.8 & & & & 0.6 \\
\hline$(\mathrm{FxV})$ & & & & NS & & & & $\mathrm{NS}$ \\
\hline \multicolumn{9}{|c|}{ Root diameter $(\mathrm{cm})$} \\
\hline $100 \mathrm{~N}+$ zero $\mathrm{B}$ & 12.1 & 13.0 & 13.2 & 12.8 & 12.2 & 12.9 & 13.1 & 12.7 \\
\hline $100 \mathrm{~N}+100$ ppm B & 13.1 & 13.5 & 13.8 & 13.5 & 12.9 & 13.1 & 13.6 & 13.2 \\
\hline $100 \mathrm{~N}+150 \mathrm{ppm} \mathrm{B}$ & 13.1 & 13.5 & 14.2 & 13.6 & 13.4 & 13.5 & 13.8 & 13.6 \\
\hline Means & 12.8 & 13.3 & 13.7 & & 12.8 & 13.2 & 13.5 & \\
\hline \multicolumn{9}{|l|}{ LSD at $5 \%$} \\
\hline Fertilization $(\mathrm{F})$ & & & & 0.5 & & & & NS \\
\hline Varieties (V) & & & & 0.2 & & & & 0.1 \\
\hline$(\mathrm{FxV})$ & & & & NS & & & & 0.2 \\
\hline
\end{tabular}

B.1. Impurities traits $(\mathrm{K} \%, \mathrm{Na} \%$ and $\alpha$ - amino $\mathrm{N} \%)$ and Alkalinity Coefficient (AC)

Data in Table (3) clear that treatments $(\mathrm{N}+\mathrm{B})$ fertilization and varieties exhibited highly significant effect on impurities parameters i.e (potassium\%, sodium \% and alpha amino nitrogen \%) and Alkalinity coefficient in both seasons. Potassium, Sodium and alpha amino $\mathrm{N}$ percentages and Alkalinity coefficient were significantly improved by (12.5 and 14.4\%), (13 and 18.3\%) and (16.2 and 28.8\%) and (9.1 and 8.3\%) when added $100 \mathrm{~N}+150 \mathrm{~B}$ compared with $100 \mathrm{~N}+$ zero B fertilization in two seasons, respectively. Whereas, early in Germany, Brieghel and Brüniche (1953) reported that $\mathrm{AC}$ is important to the buffer capacity of the juice and the carbon dioxide absorption and hence calcium elimination in the second carbonation stage. Moreover, Wieninger and Kubadinow (1971) stated that AC should not fall bellow 1.8 to prevent evaporator corrosion at high temperature of evaporation process, the increase in extractable sugar \% greatly associated with the quantity of sugar extracted from beet juice. These presant results are in agreement with those obtained Enan, (2011). Lola variety contain the lowest values of percentages compared with the others by (7and $1.9 \%)$ in potassium by $(7.4$ and $8.9 \%)$ in sodium\% and by (10.6 and $7.7 \%$ ) in alpha amino nitrogen traits in the $1^{\text {st }}$ and $2^{\text {nd }}$, respectively. On the other hand, Lola and Pleno varieties had given the minimum values (4.6 and $2.1 \%$ decreases) for Alkalinity coefficient in $1^{\text {st }}$ and $2^{\text {nd }}$ seasons, respectively.

Fayoum J. Agric. Res. \& Dev., Vol.25, No.1, January, 2011 
Aly, E.F.A.

These results are in agreement with those obtained by Aly, (2006) and Abd El-Aal et al (2010).

Table (3): Impurities (K\%, Na\% and alpha amino acid $\alpha$ - amino $\mathrm{N \%})$ as affected by nitrogen combined with boron applications of three sugar beet varieties in 2008/2009 and 2009/2010 seasons.

\begin{tabular}{|c|c|c|c|c|c|c|c|c|}
\hline \multirow{3}{*}{ Kg N/fed + Bppm } & \multicolumn{8}{|c|}{ Potassium\% $(\mathrm{K} \%)$} \\
\hline & \multicolumn{4}{|c|}{$2008 / 2009$ season } & \multicolumn{4}{|c|}{$2009 / 2010$ season } \\
\hline & Lola & Pleno & Farida & Means & Lola & Pleno & Farida & Means \\
\hline $100 \mathrm{~N}+$ zero $\mathrm{B}$ & 3.81 & 3.95 & 4.01 & 3.92 & 3.75 & 3.83 & 3.89 & 3.82 \\
\hline $100 \mathrm{~N}+100 \mathrm{ppm} \mathrm{B}$ & 3.54 & 3.79 & 3.94 & 3.76 & 3.79 & 3.68 & 3.69 & 3.72 \\
\hline $100 \mathrm{~N}+150 \mathrm{ppm} \mathrm{B}$ & 3.33 & 3.43 & 3.54 & 3.43 & 3.27 & 3.20 & 3.33 & 3.27 \\
\hline Means & 3.56 & 3.72 & 3.83 & & 3.60 & 3.57 & 3.64 & \\
\hline \multicolumn{9}{|l|}{ LSD at $5 \%$} \\
\hline Fertilization $(\mathrm{F})$ & \multicolumn{7}{|c|}{0.12} & 0.13 \\
\hline Varieties (V) & \multicolumn{7}{|c|}{0.11} & 0.07 \\
\hline$(\mathrm{F} \times \mathrm{V})$ & \multicolumn{7}{|c|}{ NS } & NS \\
\hline & \multicolumn{8}{|c|}{ Sodium\% $(\mathrm{Na} \%)$} \\
\hline $100 \mathrm{~N}+$ zero $\mathrm{B}$ & 1.46 & 1.41 & 1.52 & 1.46 & 1.60 & 1.65 & 1.67 & 1.64 \\
\hline $100 \mathrm{~N}+100 \mathrm{ppm} \mathrm{B}$ & 1.40 & 1.47 & 1.61 & 1.49 & 1.34 & 1.53 & 1.66 & 1.51 \\
\hline $100 \mathrm{~N}+150 \mathrm{ppm} \mathrm{B}$ & 1.24 & 1.26 & 1.30 & 1.27 & 1.35 & 1.27 & 1.39 & 1.34 \\
\hline Means & 1.37 & 1.38 & 1.48 & & 1.43 & 1.48 & 1.57 & \\
\hline \multicolumn{9}{|l|}{ LSD at $5 \%$} \\
\hline Fertilization $(\mathrm{F})$ & \multicolumn{7}{|c|}{0.25} & 0.13 \\
\hline Varieties (V) & \multicolumn{7}{|c|}{0.05} & 0.06 \\
\hline$(\mathrm{F} \times \mathrm{V})$ & \multicolumn{7}{|c|}{0.09} & 0.10 \\
\hline & \multicolumn{8}{|c|}{ A- amino N\% } \\
\hline $100 \mathrm{~N}+$ zero $\mathrm{B}$ & 1.18 & 1.44 & 1.28 & 1.30 & 1.26 & 1.65 & 1.48 & 1.46 \\
\hline $100 \mathrm{~N}+100$ ppm B & 1.10 & 1.19 & 1.21 & 1.17 & 1.27 & 1.27 & 1.32 & 1.29 \\
\hline $100 \mathrm{~N}+150 \mathrm{ppm} \mathrm{B}$ & 1.02 & 1.06 & 1.19 & 1.09 & 1.07 & 0.95 & 1.11 & 1.04 \\
\hline Means & 1.10 & 1.23 & 1.23 & & 1.20 & 1.29 & 1.30 & \\
\hline \multicolumn{9}{|l|}{ LSD at $5 \%$} \\
\hline Fertilization $(\mathrm{F})$ & \multicolumn{7}{|c|}{0.18} & 0.31 \\
\hline Varieties (V) & \multicolumn{7}{|c|}{0.06} & 0.10 \\
\hline$(\mathrm{F} \times \mathrm{V})$ & \multicolumn{7}{|c|}{0.10} & 0.17 \\
\hline & \multicolumn{8}{|c|}{ Alkalinity coefficient (AC) } \\
\hline $100 \mathrm{~N}+$ zero $\mathrm{B}$ & 5.05 & 4.93 & 5.20 & 5.06 & 5.02 & 4.83 & 5.02 & 4.96 \\
\hline $100 \mathrm{~N}+100 \mathrm{ppm} \mathrm{B}$ & 4.81 & 5.03 & 5.27 & 5.04 & 4.85 & 4.88 & 4.95 & 4.89 \\
\hline $100 \mathrm{~N}+150 \mathrm{ppm} \mathrm{B}$ & 4.55 & 4.62 & 4.63 & 4.60 & 4.53 & 4.54 & 4.58 & 4.55 \\
\hline Means & 4.80 & 4.86 & 5.03 & & 4.80 & 4.75 & 4.85 & \\
\hline \multicolumn{9}{|l|}{ LSD at $5 \%$} \\
\hline Fertilization $(\mathrm{F})$ & \multicolumn{7}{|c|}{0.28} & 0.34 \\
\hline Varieties (V) & \multicolumn{7}{|c|}{0.13} & 0.10 \\
\hline$(\mathrm{F} \times \mathrm{V})$ & \multicolumn{7}{|c|}{0.23} & 0.19 \\
\hline
\end{tabular}

The interaction between $(\mathrm{N}+\mathrm{B})$ treatment fertilization and varieties was reached at the level of significance for $\mathrm{Na} \%$ and $\alpha$ - amino $\mathrm{N} \%$ and Alkalinity coefficient traits in both seasons. Lola variety fertilized with $100 \mathrm{~kg}$ $\mathrm{N} / \mathrm{fed}+150 \mathrm{ppm} \mathrm{B}$ gave the minimum values of $\mathrm{Na} \%$ and alpha amino $\mathrm{N} \%$ in the 1 st season only, and Alkalinity coefficient in both seasons.

Fayoum J. Agric. Res. \& Dev., Vol.25, No.1, January, 2011 
B.2. Sucrose \% and some technological parameters

Results in Table (4) clear the significantly responses of sucrose\%, sugar lose to molasses\%, extraction sugar\% and extractability\% as affected by fertilization treatments $(\mathrm{N}+\mathrm{B})$ and varieties.

Table (4): Sucrose \%, extractable sugar \%, sugar lose to molasses\% and extractability \% as affected by nitrogen combined with boron applications of three sugar beet varieties in 2008/ 2009 and 2009/2010 seasons.

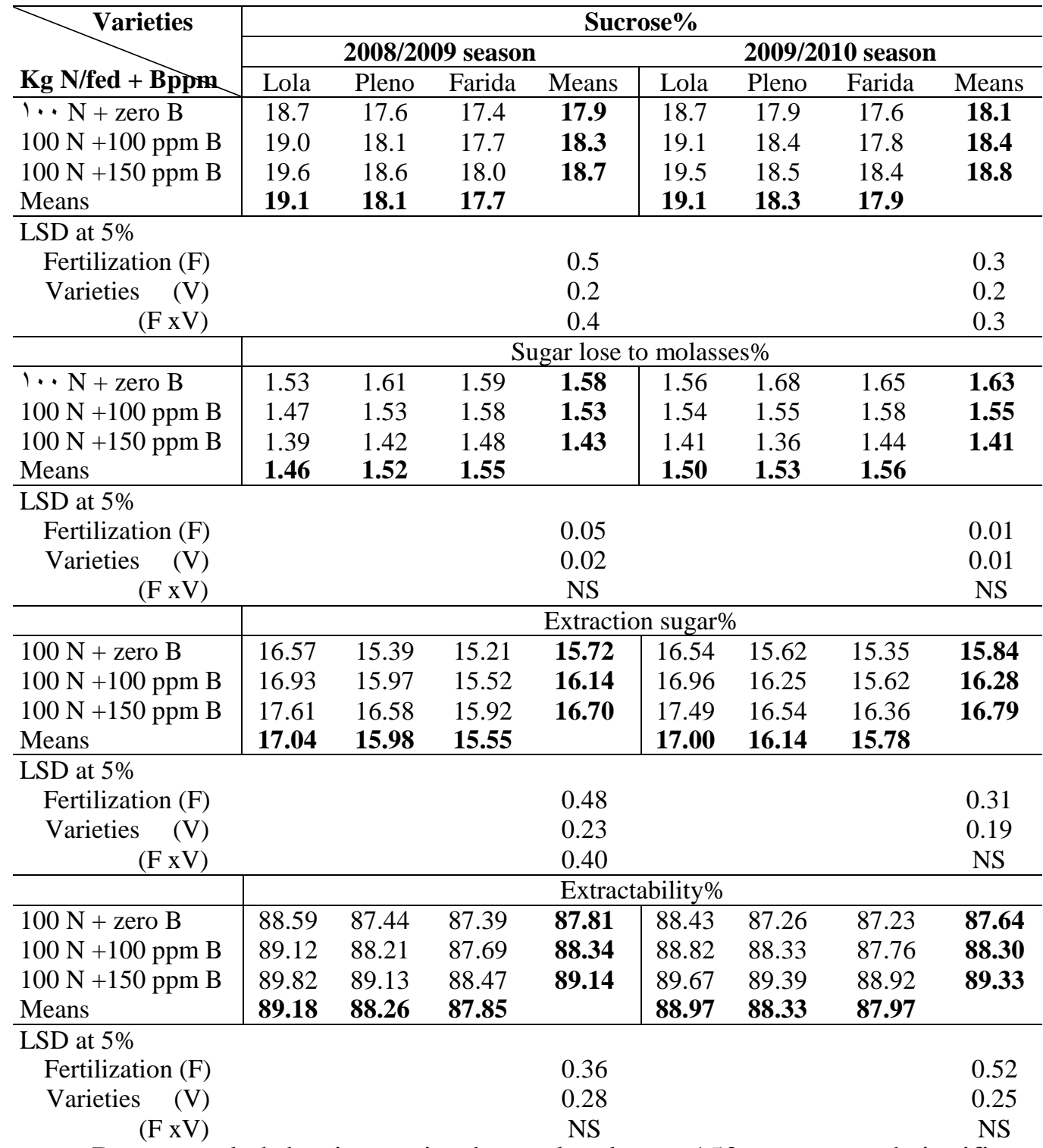

Data revealed that increasing boron level up to $150 \mathrm{ppm}$ caused significant increases in sucrose $\%$ and extraction sugar $\%$ and extractability $\%$ by $(4.5$ and $6.2 \%$ and $1.5 \%)$ in the $1^{\text {st }}$ season, and by $(3.9,13.5 \%$ and $1.9 \%)$ in the $2^{\text {nd }}$ season compared with control, while sugar loss to molasses\% was significantly decreased by (9.5 and 13.5\%) compared with control in the both seasons, respectively.

Thes results may be due to the significant differences in impurities elements (K, Na, and $\alpha$-amino $\mathrm{N} \%$ ) in juice, where these ions are difficult to

Fayoum J. Agric. Res. \& Dev., Vol.25, No.1, January, 2011 
Aly, E.F.A.

precipitate and pass through the process to the crystallization stage. On the contrary boron takes place as safe transporter factor best than or instead of potassium or sodium, moreover boron don't cause any problems through crystallization stage in sugar beet factories, so its maximize improved the quality traits. These results are in agreement with those obtained by Gobarah and Mekki (2005); Ismail, et al. (2007) and Enan, (2011).

Lola variety surpassed the other varieties in all traits as sucrose \% by (7.9 and $6.7 \%$ ), extraction sugar\% (9.6 and $9.1 \%$ ), and extractability\% by (1.5 and $1.1 \%$ ) in the $1^{\text {st }}$ and $2^{\text {nd }}$ seasons, respectively (Table 4). While Lola variety had lower values than the others by $(3.8$ and $3.8 \%)$ in both seasons for sugar lose to molasses\%. These different findings among varieties may be due to their genetic make-up or/and the varied content of impurities elements $(\mathrm{K}, \mathrm{Na}$, and $\alpha$-amino N\%) as shown in Table (3). These results are in line with those obtained Aly (2006) and Abd El-Aal et al (2010).

The interactions between fertilization treatment $(\mathrm{N}+\mathrm{B})$ and varieties were of significant effect on sucrose $\%$ in both seasons and Extraction sugar\% in the 1st season only. Lola variety and $100 \mathrm{~kg} \mathrm{~N}+150 \mathrm{ppm} \mathrm{B}$ gave the maximum values of sucrose $\%$ in both seasons and extraction sugar\% in the $1^{\text {st }}$ one only.

C. yields (t/ fed):

Table (5) illustrated that the effect of $(\mathrm{N}+\mathrm{B})$ fertilization treatments and varieties on root and recoverable sugar yields/fed.

Table (5): Root and recoverable sugar yields (t/fed) as affected by nitrogen combined with boron applications of three sugar beet varieties in 2008/ 2009 and 2009/2010 seasons.

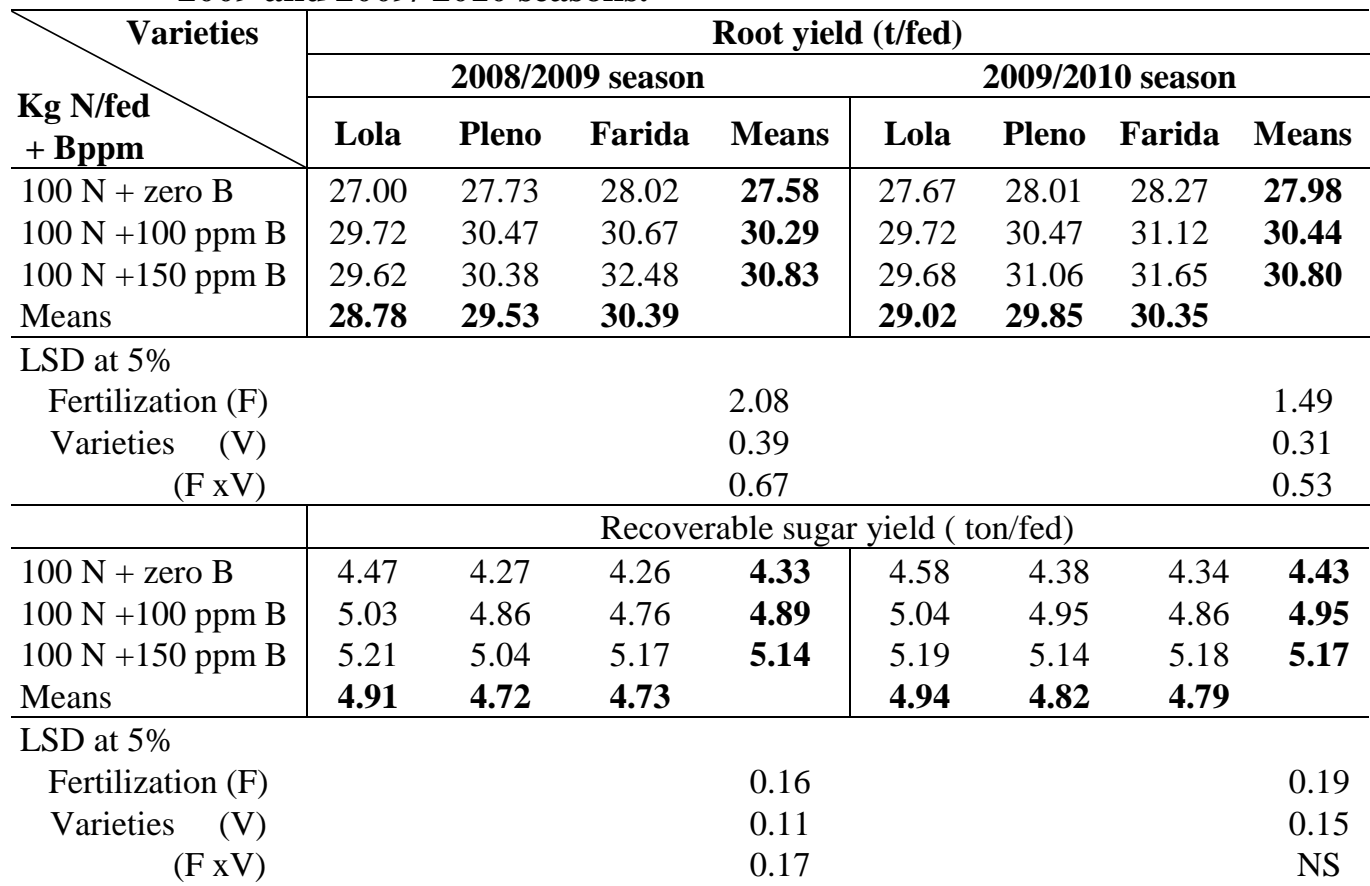

Regarding roots and recoverable sugar yields/fed, data cleared that in both seasons, increased boron up to $100 \mathrm{kgN}+150 \mathrm{ppm} \mathrm{B}$, significantly increased roots and recoverable sugar yields/fed by (11.8 and 10.4\%) and by (18.7 and $16.7 \%)$ compared with control treatment in the $1^{\text {st }}$ and $2^{\text {nd }}$ seasons, respectively. The differences between fertilization treatments effect from the $1^{\text {st }}$ and the $2^{\text {nd }}$ seasons may be basically due to significant increases in root fresh weight $(\mathrm{kg})$, as seen in Table (2). These results are in agreement with those obtained Gobarah

Fayoum J. Agric. Res. \& Dev., Vol.25, No.1, January, 2011 
Farida variety was superior to all varieties by $(5.6$ and $4.6 \%)$ in root yield/fed, while Lola variety surpassed all varieties by (4 and $3.1 \%$ ) in recoverable sugar yield/fed in both seasons, respectively. These results are in line with those obtained by Aly, (2006) and Abd El-Aal et. al. (2010).

Varieties were significantly different in root and recoverable sugar yields/fed in both seasons. These varietal differences in recoverable sugar yield/fed might due basically to their differences in root yield/ fed., contents of impurities and extraction sugar percentages as in Tables (3 and 4). These results are in line with those obtained by Aly, (2006).

Applying $\mathrm{N}+\mathrm{B}$ to sugar beet varieties showed significant effects on root yield/fed in both seasons and recoverable sugar yield/fed in the $1^{\text {st }}$ season only. Fertilized Farida variety with $100 \mathrm{~kg} \mathrm{~N} / \mathrm{fed}+150 \mathrm{ppm} \mathrm{B}$ recorded highest root yield/fed (32.48 and $31.65 \mathrm{t} / \mathrm{fed})$ in the $1^{\text {st }}$ and $2^{\text {nd }}$ seasons, respectively, while Lola variety with $100 \mathrm{~kg} \mathrm{~N} / \mathrm{fed}+150 \mathrm{ppm}$ gave the maximum recoverable sugar yield/fed in the $1^{\text {st }}$ season.

\section{REFERENCES}

Abd El-Aal, A.M.; A.I. Nafie and Ranya M. Abdel Aziz (2010). Response of some sugar beet genotypes to nitrogen fertilization under newly reclaimed land conditions. Egypt. J. Appl. Sci. 25 (6B) 194-208.

Abo EL-Hamd, A.S. and A.A. Esmail (2008). Effect of foliar potassium, magnesium and boron on yield and quality of sugar beet (Beta vulgaris, L.) growing in new reclaimed soils. J. Agric. Sci. Mansoura Univ. 33: 1737-1746.

Allen V. Baker; David J. and Pilbeam, Ed. (2007). Hand Book of Plant Nutrition. (Books in Soils, plants and the environment). Boron by Umesh C. Gpta. (p. 241278).

A.O.A.C. (1995): "Official Methods of Analysis". Association of Official Analysis Chemists, $15^{\text {th }}$ Ed. Washington, USA.

Aly, E.F.A. (2006). Effect of environmental conditions on productivity and quality of some sugar beet varieties. Ph.D., Fac. Agric., Benha Univ., Egypt.

Brieghel, M.A. and H.O. Brüniche (1953). Neuere Gesichtspunkte Zur Zweiten Saturation. Zuker 6, 443-6. (C.F. the sugar beet Crop, Book by D.A. Cooke and R.K. Scott. 1993. chapter 15. puplished by Champnon and Hall).

Carruthers, A.; J.F.T. Oldfield and H.J. Teague (1962). Assessment of beet quality. Paper Presented to the $15^{\text {th }}$ Annual Technical Conference, British Sugar Corporation LTD. 36pp. (C.F. Sugar Beet Crop Book).

Cooke, D.A. and R.K. Scott, (1993). The Sugar Beet Crop. Chapman and Hall London, p. 262-265.

Devillers, P. (1988). Prevision du sucre melasse. Scurries francases 129: 190-200. (C. F. The Sugar Beet Crop Book).

Dexter, S.T.; M.G. Frankes and F. W. Snyder (1967). A rapid of determining extractable white sugar as may be applied to the evaluation of agronomic practices and grower deliveries in the sugar beet industry. J. Am., Soc., Sugar Beet Technol. 14: 433-454. (C. F. The Sugar Beet Crop Book).

Enan, S.A.A.M. (2011). Effect of transplanting and foliar fertilization with potassium and boron on yield and quality traits of sugar beet sown under saline soil conditions. J. Biol. Chem. Environ. Sci. 6 (2): 525-546.

Gobarah, Mirvat E. and B.B. Mekki (2005). Influence of boron application on yield and juice quality of some sugar beet cultivars grown under saline soil conditions. J. Appl. Sci., Res. 1 (5): 373-379.

Fayoum J. Agric. Res. \& Dev., Vol.25, No.1, January, 2011 
Ismail, A.M.A.; A.H.S. AL-Labbody and N.M.S. Shalaby (2007). Evalution of some sugar beet varieties under different combinations of NPK fertilizers. Egypt. J. of Appl. Sci. 22(3): 2007.

Kristek A. Bisekastojic and Suzana, Kristek (2006). The effect of foliar boron fertilizer on sugar beet root yield and quality. Agric. Sci. and Proffessional Rev. 12(1).

Le-Docte, A. (1927). Commercial determination of sugar in the beet root using the sacks. Le-Docte process. Int.Sug. J. 29, 488-492.

Mostafa, Shafika N. and S. D. Darwish (2001). Biochemical studies on the fficiency use of some nitrogen fertilizers for sugar beet production. J. Agric. Sci. Mansoura 26(4): 2421-2429.

Osman, M.S.H. and Mona M. Shehat (2010). Response of sugar beet to nitrogen fertilizer and sulpher spray frequency in Middle Egypt. Egypt. J. Agric. Res. $\mathbf{8 8}(4), 2010$.

Ouda, Sohier M.M. (2007). Effect of chemical and bio-fertilizer of nitrogen and boron on yield and quality of sugar beet. Zagazig J. of Agric. Res. 34(1), 1-11.

Page, A.L. (1982). "Methods of Soil Analysis". Chemical and Microbiological Properties. $2^{\text {nd }}$ ed., Agron. 9, Am. Soc. Agro. Inc. Publ. Madison, Wis, USA.

Snedecor, G.W. and W.G. Cochran (1967). Statistical Methods. $7^{\text {th }}$ Ed. Iowa State Univ., Press., Emes., Iowa USA : 325-330.

Wieninger, L. And N Kubadinow (1971). Beziehungen Zwischen Rubenanalysen und technologische Bewertung Von Zuckerruben. Incomptes Rendus dela 14 Assemblee Generale de la commission Internationale Technique de sucerie. Pp523-538. (C.F. the sugar beet crop, book by D.A. Cooke and R. K. Scott (1993) Chapter 15. Published by Champnon and Hall).

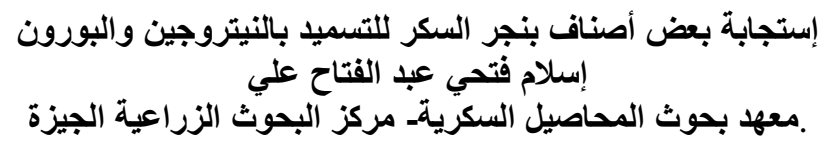

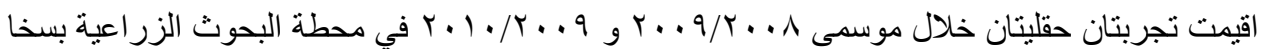

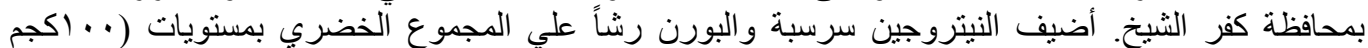

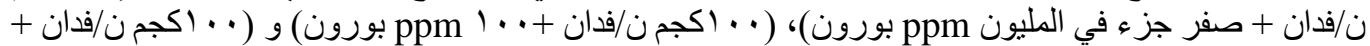

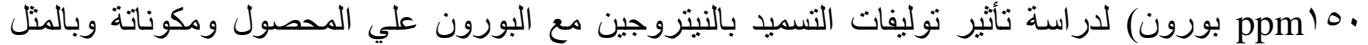
صفات الجودة لثلاثة اصناف من بنجر السكر (لو لا وبلينو وفريده) أوضحت النتائج الّتحصل عليها مائيلي:

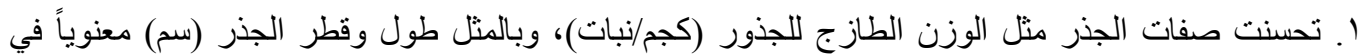

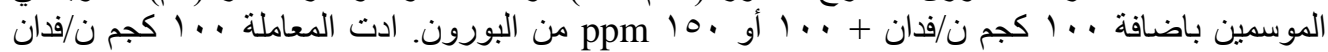

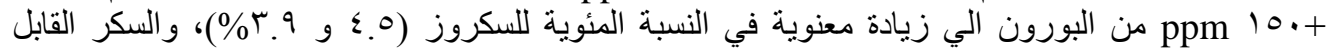

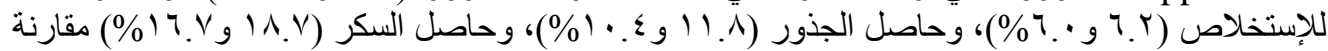

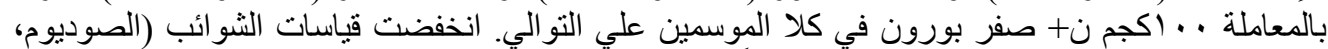

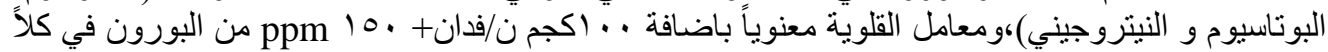

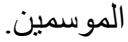

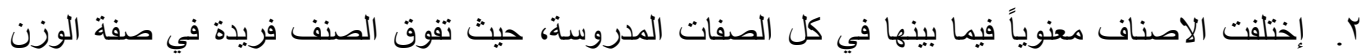

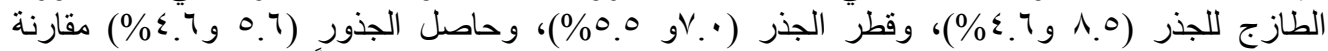

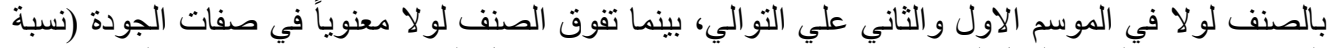
السكروز، نسبة السكر القابل للاستخلاص، نسبة الاستخلاص)، وحاصل السكر (طن/فدان) في كلا الموسمين.

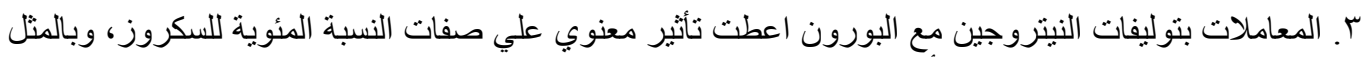
حاصلا الجذور و السكر للفدان للأصناف المدروسة.

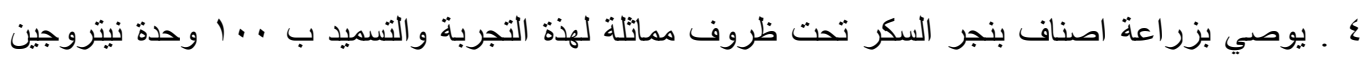

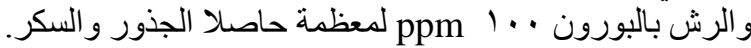

Fayoum J. Agric. Res. \& Dev., Vol.25, No.1, January, 2011 